brought together 48 scientists and resource managers from all over Asia - including Afghanistan, Pakistan, India, Nepal, Sri Lanka, Thailand, Bangladesh, Malaysia, Indonesia, China, and Japan. An outcome of that initiative has been the informal Asian Conservation Network which functions with its secretariat at the Centre.

Besides the above major training programmes and pertinent activities there have been several ecodeve- lopment and Nature camps conducted by the Centre in the rural areas of the Western Ghats.

\section{R.J. RANJIT DANIELS Centre for Ecological Sciences Indian Institute of Science Bangalore 560012 India.}

\title{
USSR Becomes IUCN's Fifty-fourth Nation-state Member
}

The Soviet Union became IUCN's 54th state member in April of this year*, and the first from the eastern European region. Approval for membership was sought and obtained from all fifteen Republics of the USSR - a notable achievement in a time of ethnic tension and nationalist sentiment, demonstrating once more that concern for the environment has the power to bring people together to achieve shared goals. It is, however, not so surprising in a country where opinion polls consistently show that the environment is a major source of public concern.

In spite of media concentration on the dark side of the Soviet environment, its vast region contains many species and habitats that have all but disappeared from western Europe, and wildlands that are hard to find anywhere else. IUCN hopes to be able to cooperate with its new State

* A notice at the time indicated that 'The Soviet decision was communicated to the Union by Dr Vladimir Sakharov, Head of International Relations of the Ministry for Nature Conservation and Environmmental Protection of the USSR, [when he was] attending a meeting in Geneva ... of the United Nations Economic Commission for Europe. The United States also [only] recently joined the World Conservation Union as a state member.' - Ed. member in formulating and implementing policies and strategies that conserve the rich natural heritage while at the same time allowing and even encouraging non-destructive economic development.

An IUCN National Committee will be formed in the USSR, representing all its Republics and the scientific and conservation community, and will embark on development of a joint programme with IUCN. The first meeting of the Committee is scheduled for the autumn of 1991. A Secretariat to service the Committee and coordinate IUCN-Soviet activities will be established in the AllUnion Institute for Nature Protection and Reserves, Moscow, USSR.

Meanwhile, the IUCN East European Programme and its partners in the Soviet Union have not been idle, and the third and last volume of national environmental status reports, which covers the European USSR, is in press and will be published shortly.

\section{ElizabeTH Hopkins, Co-director \\ East European Programme \\ The World Conservation Union (IUCN) \\ Avenue du Mont-Blanc \\ 1196 Gland, Switzerland.}

\section{Leading Champions of Wildlife Lost to Dastardly Acts}

With, surely, the rest of the civilized world, the International Society of Naturalists (INSONA) deeply mourns the brutal assassination, under the most extraordinarily tragic circumstances, of the former Prime Minister and former Chairman of the Indian Board for Wildlife, Shri Rajiv Gandhi, on 21 May 1991. It is a sad loss indeed to the environmental and wildlife conservation movement in the Indian subcontinent.

Shri Rajiv Gandhi helped in our crusade to save the habitat of Antelope cervicapra - the endangered Blackbuck (Gaekwad \& Oza, 1988). Earlier, in our endeavours to save the Kashmir Deer (Cervus elaphus hanglu), popularly known as the Hangul, from the brink of extinction, the late Prime Minister Smt. Indira Gandhi, as the then Chairperson of the Indian Board for Wildlife had graciously extended support (Oza, 1987). She also helped in my attempts to have the Silent Valley recognized as a World Heritage Site (Oza, 1981; Venkateswaran \& Polunin, 1984).

India achieved several conservation successes during the time when Indira and then Rajiv Gandhi served as the Prime Ministers of the world's second most populous country. Nature lovers and conservationists described that period as 'now or never' for serving the cause of wildlife conservation. So altogether it is a multiply shocking trajedy that earlier the Mother, and then recently the Son, who both rendered paramount services to save Indian wildlife, have been done to death in the most tragic and barbaric circumstances, when the Nation needed their services the most.

Smt. Indira Gandhi's tragic end came on 31 October 1984, in New Delhi, in her Prime Minister's residence at the treacherous hands of her own armed bodyguards. Campaigning intensively and extensively during the 1991 Indian election, her only surviving Son, Shri Rajiv Gandhi, travelled almost everywhere freely, mixed among the masses fearlessly, even sweeping aside the security shields, warnings, and obstacles.

He lost his precious life to brutal, dare-devil assassination on 21 May 1991 in Sriperumbudur (Kancheepuram taluk, Chengai-Anna district, on the Madras-Banglore highway). The latest intelligence reports which appeared in the Press reveal that the disastrous end could have occurred elsewhere during the campaign if the assassin(s) failed to strike the death-blow near Madras.

Shri Rajiv Gandhi was annihilated, on that fateful night in Sriperumbudur, by the suicide mission of the 'belt-bomb' woman, who, it is believed, waited to garland him. Eye-witnesses narrated that she could have bent forward with an intention to touch his feet - as a mark of respect - and consequently could have activated a timer, triggering the explosion. The woman, it is reported, had tied the 'live bomb' belt to her back. 